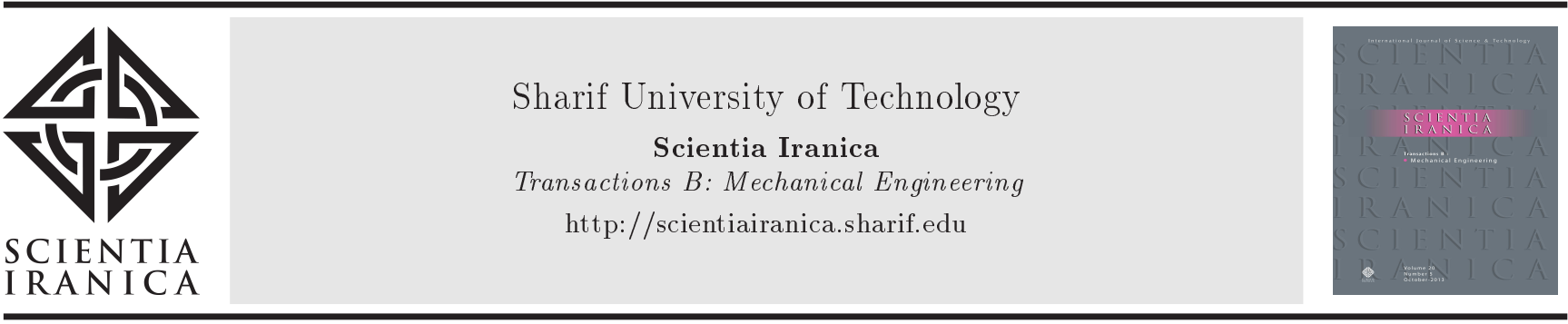

\title{
Performance study of an innovative heating technique for a modified solar still
}

\author{
A.E. Kabeel ${ }^{\mathrm{a}}$, M.M. Bassuoni ${ }^{\mathrm{a}, \mathrm{b}, *}$, and M.A. Rozza ${ }^{\mathrm{a}}$ \\ a. Department of Mechanical Power Engineering, Faculty of Engineering, Tanta University, Egypt. \\ b. Department of Mechanical Engineering, Faculty of Engineering, Taif University, Al Haweiah, P.O. Box 888, 21974, Saudi Arabia.
}

Received 14 May 2016; received in revised form 19 January 2017; accepted 6 March 2017

\section{KEYWORDS}

Solar still;

Desalination;

Solar energy.

\begin{abstract}
An experimental comparison of water productivity between a conventional single slope, solar still, and a modified one is introduced in this work. The modified solar still is incorporated with a new heating technique on the saline water surface using finned cover with holes. These fins are used to increase the heat transfer area between the cover and saline water; meanwhile, holes are used to allow evaporated water to go through. These experiments are held under the outdoor conditions of Tanta, Egypt. The performance of the two solar stills has been tested at a water depth of $0.05 \mathrm{~m}$ and a quantity of saline water of $50 \mathrm{~L}$. The results indicated that the productivity of water per square meter per day for the modified design still is higher than the conventional still by about $30.6 \%$.

(C) 2018 Sharif University of Technology. All rights reserved.
\end{abstract}

\section{Introduction}

Solar stills of different designs have been investigated by many researchers. Arunkumar et al. [1] studied the effect of hemispherical solar still with and without cooling for this cover on the productivity of fresh water. The maximum productivity is achieved by cooling the cover compared to the cover without cooling its surface and enhancing radiation by a factor of 1.25 .

Ahsan et al. [2] investigated new design, fabrication and performance of tubular solar still in their design. They tried to reduce the weight and increase the durability of their still using available materials resulting in a cost reduction of still. These changes had their effect by reducing both cost and weight by $92 \%$ and $61 \%$, respectively.

Rajamanickam and Ragupathy [3] studied the influence of water depth in a double-slope solar still

\footnotetext{
*. Corresponding author.

E-mail addresses: kabeel6@hotmail com (A.E. Kabeel) mahgoub.m@gmail.com (M.M.Bassuoni)
}

compared to a conventional single-slope solar still. The comparison was held with fixed feed water conditions and at the same ambient temperature with south direction facing the sun and wind. The experiments were performed at three different levels of water, and revealed that productivity is inversely proportional to water depth. The maximum productivity was achieved for the double-slope solar still.

Panchal and Shah [4] investigated solar stills with floating plates. They manufactured three solar stills with the same area. The first one with a floating aluminum plate and the second one with a galvanized iron plate; however, a third one is conventional which is set as the reference still. The plates will play a role as a heat storage element to increase the evaporation. The experiment proves that the aluminum plates had the maximum productivity than iron plates and conventional solar still; further, they found that the productivity is proportional to the solar intensity.

Omara et al. [5] improved the single-slope solar still by increasing heat transfer surface area. They created two different modified bases in the solar still: the first base with the addition of fins; the second one corrugated to increase surface area. The third 
still was conventional compared with the first two stills. They found that both modified solar stills have greater productivity, meaning that as the surface area increased, the productivity also increased. The finned base solar and corrugated solar stills recorded a maximum increase of productivity by about $40 \%$ and $21 \%$, respectively.

A pyramid-shaped solar still was studied by Taamneh and Madhar [6]. They added a fan operating with photovoltaic solar panels that will create a forced convection resulting in a high evaporation rate and increasing the productivity. They compared free convection pyramidal solar still with the forced convection one. The results proved that the forced convection increases the productivity more than free convection by $25 \%$.

Abdul-Wahab and Al-Hatmi [7] designed and analyzed an inverted solar still integrated with a refrigeration cycle. In their experiment, they studied the relation between water depth and feed-water temperature with the productivity. They proved that, at high levels of water, the productivity increased in contrast with normal conventional solar stills, whose productivity increased at lower levels.

Dashtban and Tabrizi [8] investigated weir-type cascade solar still integrated with phase-changing martial to keep latent heat during sunshine hours on the lake till nightfall. In their experiment, they studied the system with and without PCM and recorded the productivity of both cases. They concluded that productivity is increased by $31 \%$ for the system with PCM.

Kabeel et al. [9] improved the stepped solar still by putting the water in trays which are different in length and depth. They compared the productivities and performances of the stepped solar and conventional solar stills; moreover, they used vacuum tube solar collector to control the feed-water temperature entering the still. They concluded that maximum productivity was achieved with a tray dimension of $50 \mathrm{~mm}$ depth and $120 \mathrm{~mm}$ length. Also, the productivity increased by about $57.3 \%$, compared to conventional solar still.

Monowe et al. [10] developed a new solar still with an external boosting reflector to increase solar radiation in the solar still. They added a condenser to still, which played two important roles in the experiment. The first role is cooling and condensing the product water, and the second role is warming up the feed water to the still. The efficiency of such a still reached up to $77 \%$ if the preheated saline water was used for domestic purposes, and it was up to $85 \%$ if preheated saline water was used to operate the still during night times and recharge the still by the next batch of preheated water.

Tanaka [11] investigated theoretically the performance of a solar still incorporated with solar reflector to increase the amount of reflected rays from the sun. He calculated the best angle to the reflector during winter, summer, and spring. He predicted theoretically the amount of productivity in the spring, summer, and winter, which were $41 \%, 25 \%$, and $62 \%$, respectively.

Moreover, Tanaka [12] introduced a theoretical analysis of the performance of a tilted wick solar still with solar reflectors on the bottom edge of the reflector. His study was done in the four seasons: winter, summer, spring, and autumn. He predicted that the best inclination angle for spring, autumn, and winter was greater than $15^{\circ}$ and for the summer was greater than $25^{\circ}$.

Velmurugan et al. [13] studied the effect of modifying the area of the basin. They studied a solar still with sponge inside due to capillary force of sponge to suck water and increase of heating surface. The productivity of their still increased by about $15.3 \%$ compared to conventional solar still.

El-Sebaii and El-Naggar [14] studied a theoretical and experimental model for a solar still with a finned basin liner made of copper. They studied the yearround performance of the still in terms of the monthly average of daily productivity and efficiency. It was also inferred that the fin material did not affect the still productivity.

From the previous researches, it is clear that increasing the basin area affects the overall productivity of the solar still positively. Therefore, the aim of this study is to compare the performance of conventional single-slope basin solar still with that of a modified solar still. The modified still uses a new heating absorber on the water surface integrated with fins to increase contact area. The novelty in the modified still is that heating process for water occurs from the absorber (covered with fins and holes) (i.e., top heating). On the other hand, the conventional system heats water from solar basin (bottom).

\section{Experimental setup}

Two solar stills are designed and constructed to compare the performance of the proposed modified solar desalination system with the conventional still. A photograph of the experimental setup of both stills is shown in Figure 1. The setup consists of a saline water tank, a conventional still (single basin solar still), and a finned cover solar still.

\subsection{Conventional solar still}

Basin area of the conventional still is $1 \mathrm{~m}^{2}(50 \mathrm{~cm} \times$ $200 \mathrm{~cm}$ ), the high-side wall depth is $45 \mathrm{~cm}$, and the lowside wall height is $16 \mathrm{~cm}$. The still is made of galvanized iron sheets (1.5 mm thick). The whole basin surfaces are coated with black paint from inside to increase their absorptivity. In addition, the still is insulated 


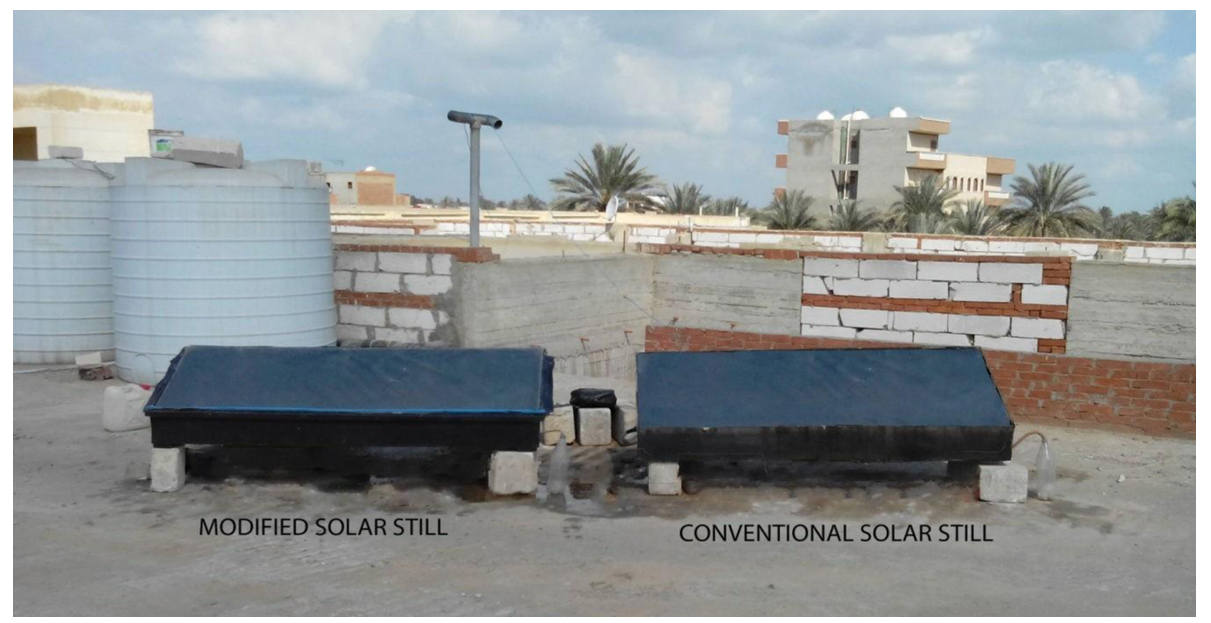

Figure 1. Photograph of the experimental set up.

from the bottom and side walls with sawdust of $40 \mathrm{~mm}$ thick to reduce the heat loss from the still to ambient temperature. The insulation layer is supported by a wooden frame. The basin is covered with glass sheet of $3 \mathrm{~mm}$ thickness inclined with nearly $30^{\circ}$ on the horizontal, which is the latitude of the Tanta city, Egypt. Silicon was used as a seal to prevent leakage from any gap between the glass covers and still box.

\subsection{Modified solar still}

The modified still has the same construction of the conventional one compared to the cover with nineteen fins. These fins are welded to the cover to increase the heat transfer surface area. Further, the cover is punched with 180 holes, each with $20 \mathrm{~mm}$ diameter, to allow evaporation to go up through. Figure 2 shows a schematic diagram of the modified solar still cover with fins. These fins are made up of iron sheet of 1.5 mm thick and each has an area of $(5 \mathrm{~cm} \times 48 \mathrm{~cm})$. The interval space between each of two fins is $10 \mathrm{~cm}$. The holes are distributed in twenty rows; each row has nine holes. The space between each of two holes is $5.5 \mathrm{~cm}$. Figure 3 shows a photograph of the modified solar still.
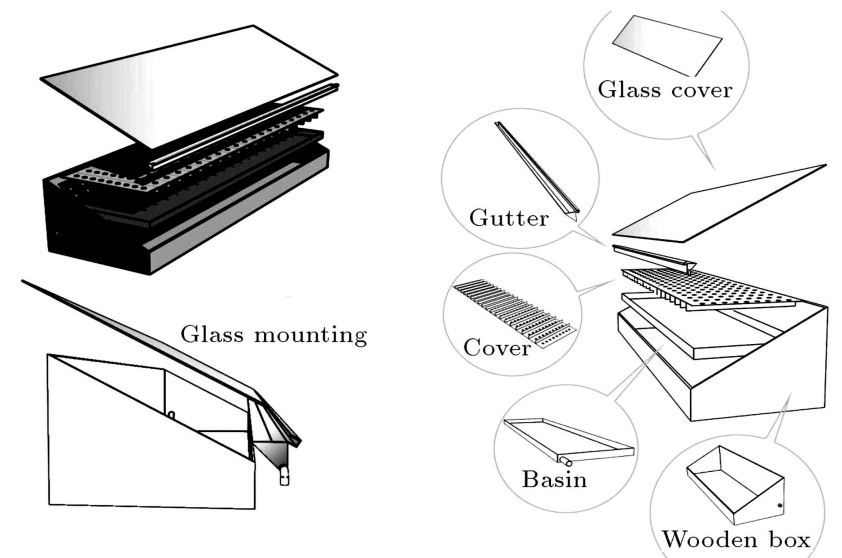

Figure 2. A schematic for components of the modified solar still.

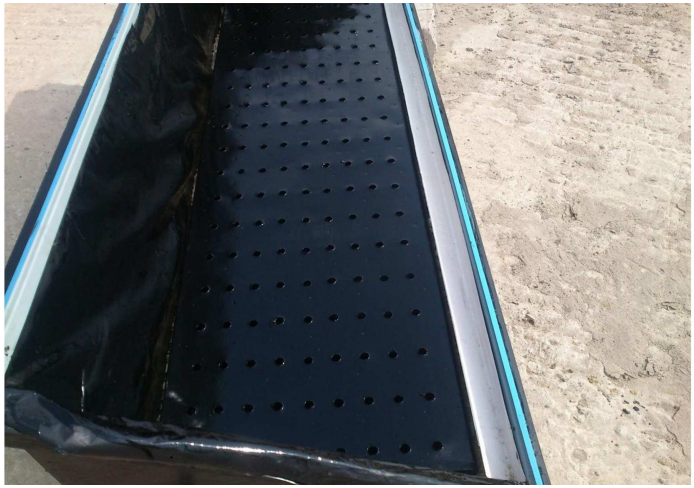

Figure 3. Photograph of the modified solar still.

\section{Experimental procedure}

Experiments were conducted at the Faculty of Engineering Tanta University, Egypt. The experiments were carried out in the period of 9 a.m. to the sunset during July 2014. The solar radiation, atmospheric temperature, basin temperature, saline water temperature, glass temperature, and distilled water productivity were measured every 1 hour. However, the accumulated productivity during the 24 hours was measured in each experiment.

The present experimental study aims to study the effect of heating the free surface of water on freshwater productivity and the efficiency of the basin still in two different cases. The first one is conducted at equalizing the saline water depth in the two tested solar stills $(0.05 \mathrm{~m})$, while the second is conducted at equalizing quantity in two tested solar stills (50 L).

\section{Results and discussion}

Prior to the experimental discussion, a comparison between the present study and that of Omara et al. [5] is introduced in Figure 4. The comparison shows that the modified solar still has the greatest 


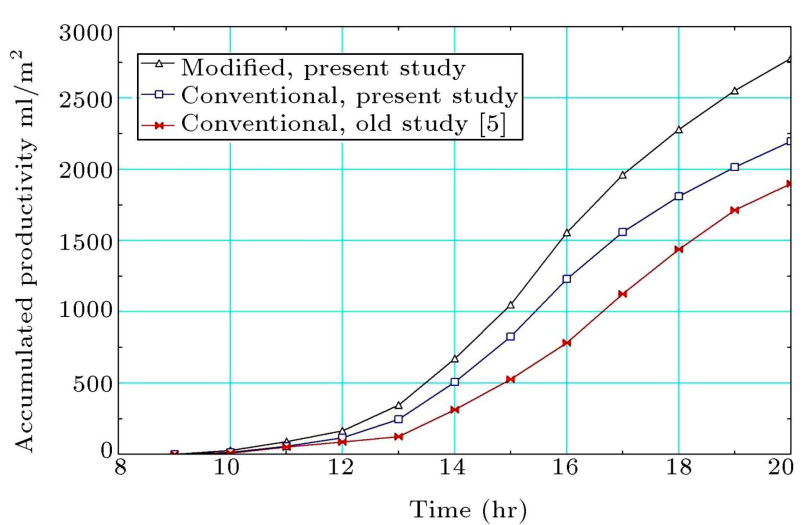

Figure 4. Comparison between the present work and [5].

accumulated productivity by about $34.3 \%$ compared to [5]. Depending upon climate condition, the wind speed varied from 0.5 to $6.5 \mathrm{~m} / \mathrm{s}$ and solar intensity varied from 20 to $1000 \mathrm{w} / \mathrm{m}^{2}$, the performances of both solar stills were measured at constant water depth and constant quantity of water.

\subsection{Effect of solar intensity on the performance of solar stills}

The variations of solar intensity, ambient temperature, and water temperature for both stills are shown in Figure 5. As shown in the figure, the temperature increases as solar intensity increases, reaching the maximum value at afternoon and starting to decrease afterwards.

In addition, in Figure 5, the maximum increase in temperature takes place from 1:30 p.m. until 4:00 p.m. It is noticed that the variation between water temperatures of modified and conventional solar stills is about $0: 5.75^{\circ} \mathrm{C}$. This variation can be explained as a result of fins integrated with still cover which increases the heat transfer surface area.

The temperatures of the modified cover with fins (absorber) and increasing in water temperature for both modified and conventional stills are monitored as shown in Figure 6. From this figure, it is noticed

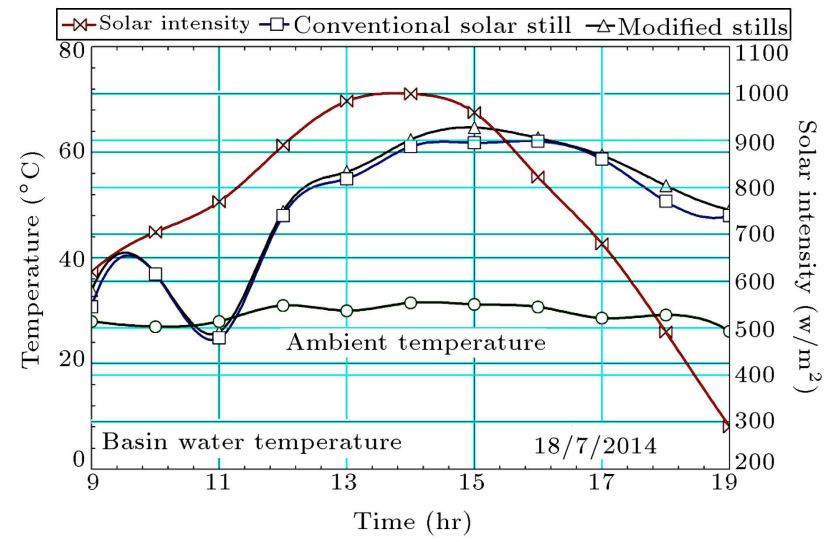

Figure 5. Basin water temperature variation with solar radiation.

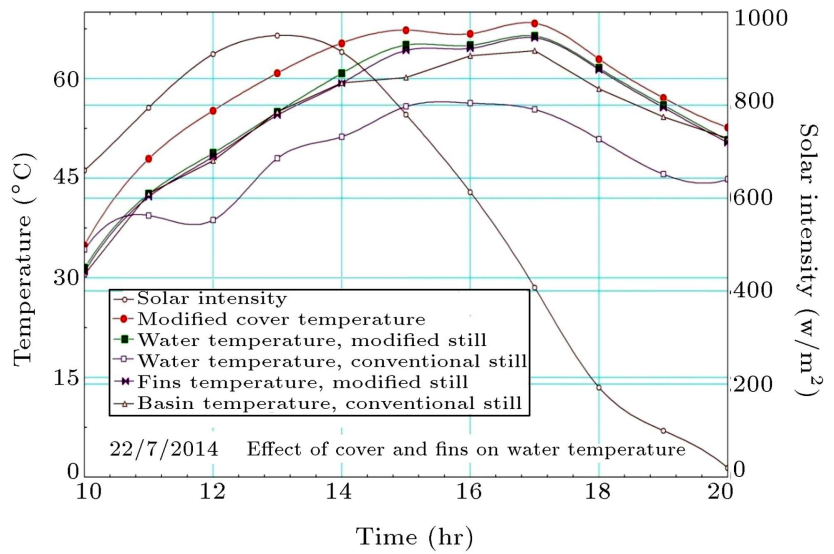

Figure 6. Basin water and steel temperature variations with solar radiation.

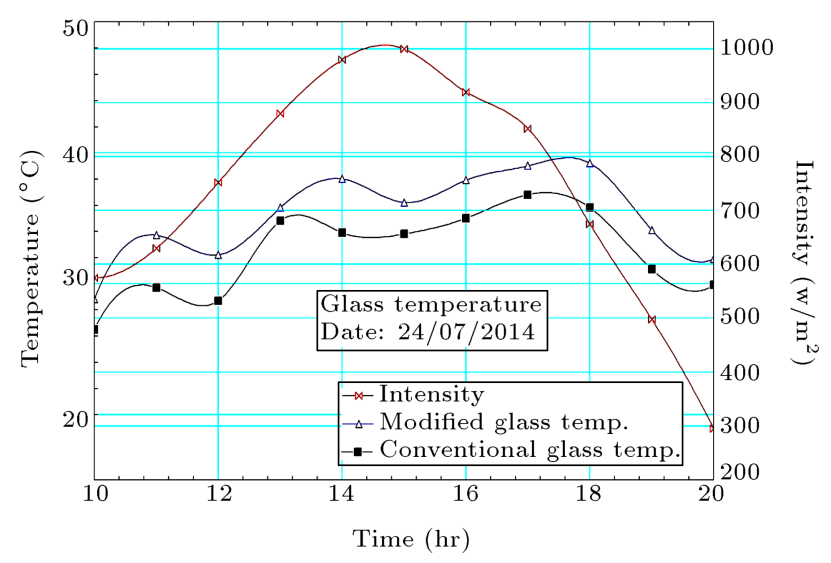

Figure 7. Glass cover temperature variation with solar radiation.

that the heat loss between modified cover and water in the proposed solar still is smaller than that between water and metal sheets of conventional still. The water productivity of modified still is increased compared to the conventional still due to water temperature increase.

In Figure 7, the variation of glass temperature for both modified and conventional stills is registered. The glass temperature of the modified still is increased from $0: 3.6^{\circ} \mathrm{C}$, this increase in temperature refers to the increase in amount of evaporation in modified still than that in the conventional still.

\subsection{Results of both stills at constant water depth $(5 \mathrm{~cm})$}

A compassion between the hourly productivity of both conventional and modified solar stills at constant depth is illustrated in Figure 8. The productivity increases with time until reaching the maximum value at afternoon, and then decreases.

In addition, it is noticed from Figure 9 that the productivity of modified solar still is more than that of conventional still for the following reasons. The design of heating surface absorber allows surface 


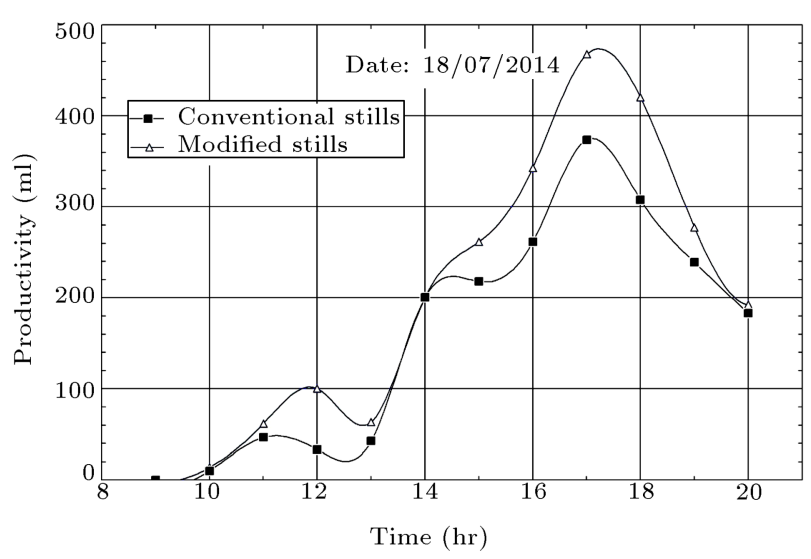

Figure 8. Hourly productivity for conventional and modified stills (constant depth).

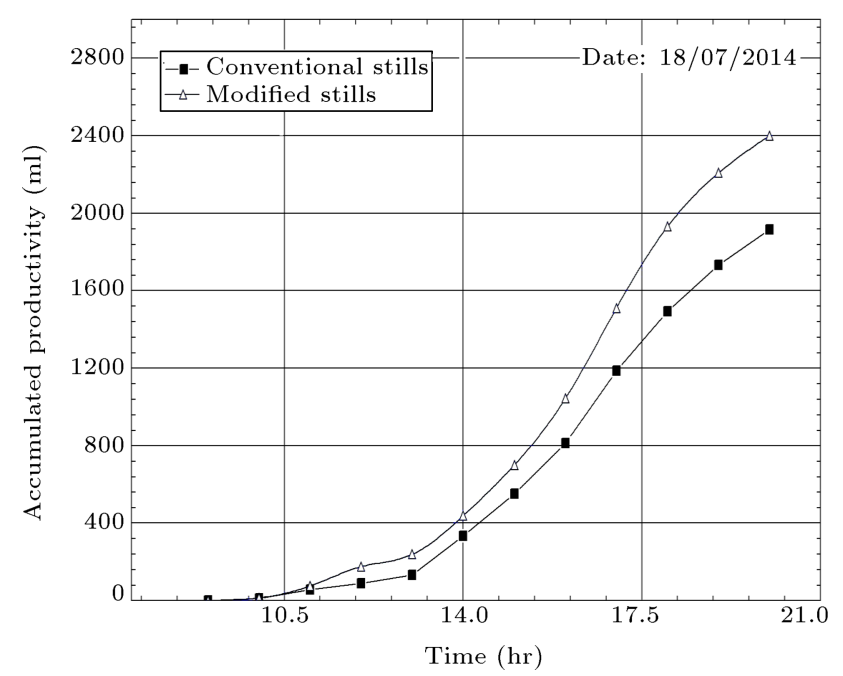

Figure 9. Accumulated productivity of conventional and modified stills (constant depth).

particle to evaporate freely, the cover surface area of modified still is much larger than conventional one (1.43 $\mathrm{m}^{2}$ and $1 \mathrm{~m}^{2}$, respectively), and the quantity of water in conventional still is more than that in modified still (50 L and $48.9 \mathrm{~L}$, respectively). The difference in quantities of water occurs at constant depth experiments, as the extra volume of the fins in a modified still results in a decrease of water quantity of $(48.9 \mathrm{~L})$, compared to $50 \mathrm{~L}$ for the conventional one.

\subsection{Results of both stills at constant quantity of saline water}

A comparison between the hourly productivities of both conventional and modified solar stills at a constant quantity of saline water is illustrated in Figure 10. It is apparent that the modified still has higher productivity than the conventional one due to the fact that adding fins to basin solar still decreases the preheating time required for the evaporating process [13]. Moreover, fins increase projected surface area of the absorber.

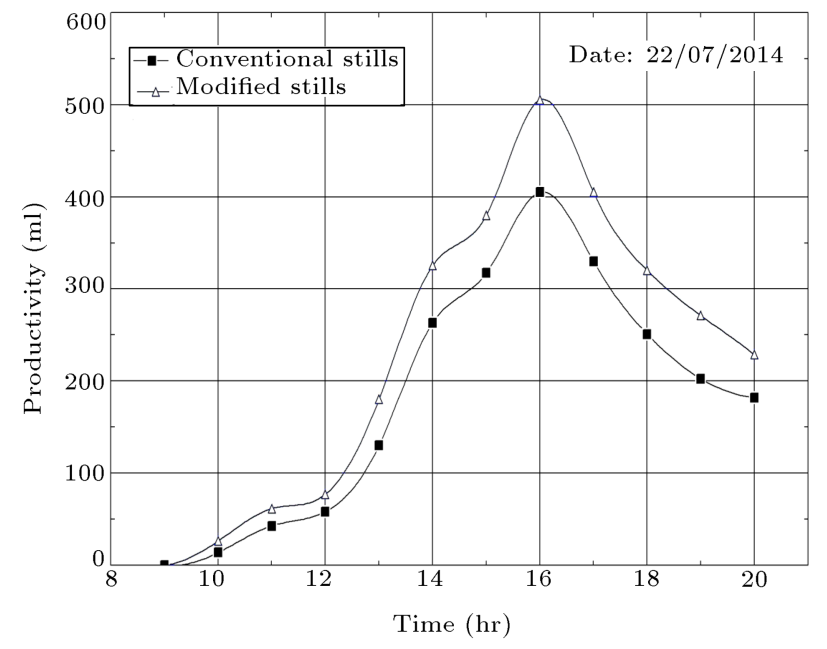

Figure 10. Hourly productivity for conventional and modified solar stills (constant quantity).

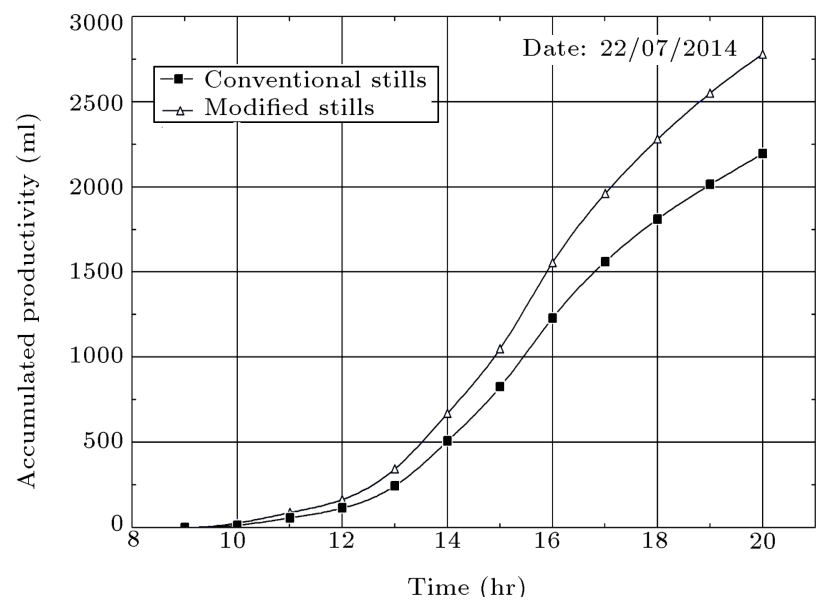

Figure 11. Accumulated productivity for conventional and modified solar stills (constant quantity).

Further, accumulated productivity is presented in Figure 11, clearly showing that the modified solar still has maximum productivity. The equilibrium between water in the basin and atmosphere occurs nearly between 8.30 and $9.00 \mathrm{pm}$.

Measurements of accumulated distillate water during experiments are tabulated in Table 1 . It is clear from this table that the modified solar still at constant depth and quantity has a higher productivity by approximately $20-30 \%$, respectively, as compared to conventional still.

\section{Conclusion}

From the presented experimental results of innovative and conventional stills, the following conclusions can be summarized:

1. The performance of a solar still is strongly influenced by changing the place of the heating absorber 
Table 1. Accumulated distillate (mL/day) water during the experiments.

\begin{tabular}{ccccc}
\hline \multirow{2}{*}{ Day } & \multicolumn{3}{c}{ Climate conditions } & \\
\cline { 2 - 4 } & $\begin{array}{c}\text { Wind speed } \\
(\mathbf{m} / \mathbf{s})\end{array}$ & $\begin{array}{c}\text { Ambient temperature } \\
\left({ }^{\circ} \mathbf{C}\right)\end{array}$ & Modified & Conventional \\
\hline & & & Productivity at constant depth (mL/day) \\
$18 / 7 / 2014$ & 2.96 & 29.2 & 2400 & 1915 \\
$19 / 7 / 2014$ & 2.79 & 31.9 & 1886.25 & 1580 \\
$20 / 7 / 2014$ & 2.10 & 28.2 & 2052.5 & 1578 \\
& & & Productivity at constant quantity (mL/day) \\
$22 / 7 / 2014$ & 5.37 & 30.2 & 2780 & 2196 \\
$23 / 7 / 2014$ & 4.01 & 32 & 2390 & 1883.8 \\
$24 / 7 / 2014$ & 7.36 & 29.4 & 2590.5 & 2265 \\
\hline
\end{tabular}

(modified cover with fins) also with the variation of contact area with the basin;

2. At a constant water depth, the amount of fresh water per square meter from modified still is higher than conventional still by about $20 \%$ per day;

3. At constant saline water quantity, the amount of fresh water produced from modified still per square meter could be higher than conventional still by about $30 \%$ per day;

4. The estimated costs per 1 litter of distillate water for conventional and modified solar stills are $0.062 \$$ and $0.042 \$$, respectively.

\section{Acknowledgment}

The authors wish to take this opportunity to express their sincerest appreciation to the Higher Institute of Engineering at Tanta, Egypt for its serious help to finish building up the experimental setup in its labs.

\section{References}

1. Arunkumar, T., Jayaprakash, R., Denkenberger, D., Amimul Ahsan, Okundamiya, M.S., Sanjay Kumar, Hiroshi Tanaka, Aybarg, H.Ş "An experimental study on a hemispherical solar still", Desalination, 286, pp. 342-348 (2012).

2. Ahsan, A., Imteaz, M., Rahman, A., Yusuf, B., and Fukuharad, T. "Design, fabrication and performance analysis of an improved solar still", Desalination, 292, pp. 105-112 (2012).

3. Rajamanickam, M. and Ragupathy, A. "Influence of water depth on internal heat and mass transfer in a double slope solar still", Energy Procedia, 14, pp. 17011708 (2012).

4. Panchal, H. and Shah, P.K. "Investigation on solar stills having floating plates", International Journal of Energy and Environmental Engineering, 3(1), pp. 1-5 (2012).
5. Omara, Z., Hamed, M.H. and Kabeel, A. "Performance of finned and corrugated absorbers solar stills under Egyptian conditions", Desalination, 277(1), pp. 281287 (2011).

6. Taamneh, Y. and Taamneh, M.M. "Performance of pyramid-shaped solar still: Experimental study", Desalination, 291, pp. 65-68 (2012).

7. Abdul-Wahab, S.A. and Al-Hatmi, Y.Y. "Study of the performance of the inverted solar still integrated with a refrigeration cycle", Procedia Engineering, 33, pp. 424-434 (2012).

8. Dashtban, M. and Tabrizi, F.F. "Thermal analysis of a weir-type cascade solar still integrated with PCM storage", Desalination, 279(1), pp. 415-422 (2011).

9. Kabeel, A., Kabeel, A.E., Khalil, A., Omara, Z.M., and Younes, M.M. "Theoretical and experimental parametric study of modified stepped solar still", Desalination, 289, pp. 12-20 (2012).

10. Monowe, P., Masale, M., Nijegorodov, N., and Vasilenko, V. "A portable single-basin solar still with an external reflecting booster and an outside condenser", Desalination, 280(1), pp. 332-338 (2011).

11. Tanaka, H. "A theoretical analysis of basin type solar still with flat plate external bottom reflector", Desalination, 279(1), pp. 243-251 (2011).

12. Tanaka, H. "Tilted wick solar still with flat plate bottom reflector", Desalination, 273(2), pp. 405-413 (2011).

13. Velmurugan, V., Gopalakrishnan, M., Raghu, R., and Srithar, K. "Single basin solar still with fin for enhancing productivity", Energy Conversion and Management, 49(10), pp. 2602-2608 (2008).

14. El-Sebaii, A.A. and El-Naggar, M. "Year round performance and cost analysis of a finned single basin solar still", Applied Thermal Engineering, 110, pp. 787-794 (2017). 


\section{Biographies}

Abd Elnaby Elbaiomy Kabeel is a Professor at the Department of Mechanical Engineering at the University of Tanta, Egypt. Now, he is the Vice Dean for Postgraduate Studies and Research. In the same faculty and university, he was the Head of Mechanical Power Engineering Department, from 2013 to 2016 and the Vice dean for Community Service and Environment Development, from 2010 till 2013. He harvested many scientific awards, the most recent of which was Shoman prize for Arab researchers, 2014. His research interests lie in the area of thermal energy science. In recent years, he has focused on better techniques for enhancing thermal processes, especially in cooling and desalination programs. He has about 180 research papers in international journals and conferences.

Mohamed Mahgoub Bassuoni is an Associative
Professor at the Department of Mechanical Engineering at the University of Tanta, Egypt where he has been a faculty member since 2000 (permanent address). His current address is now at Taif University-KSA.

His research interests lie in the area of thermal science. In recent years, he has focused on better techniques for expressing, analyzing, and executing desalination programs. He has collaborated actively with researchers in several other disciplines of hybrid air conditioning.

Mohamed Atef Rozza is a Mechanical Engineer at West Delta Electricity Production Company ABO QIR thermal power station Alexandria Egypt since 2011(permanent address). His research interests lie in the area of thermal energy science. In recent years, he has focused on creating a new design to enhance performance and the technique which solar system used to increase productivity, especially in solar still, which used to desalt water. 